\title{
ASSOCIATIVE CONCEPTUAL CONSTANT OF SUBCONCEPTS E-SPACE AND CYBERSPACE
}

\author{
Anastasiia Kopytina \\ Postgraduate Student, Lecturer at the Department of Typology and Romance Languages, \\ Borys Grinchenko Kyiv University, Ukraine \\ e-mail: a.kopytina@kubg.edu.ua,orcid.org/0000-0002-6083-7385
}

\section{Rusudan Makhachashvili}

Doctor Habilitated of Philology, Associate Professor, Head of the Department of Typology and Romance Languages, Borys Grinchenko Kyiv University, Ukraine e-mail: r.makhachashvili@kubg.edu.ua,orcid.org/0000-0002-4806-6434

\section{Summary}

The article presents the part of results of a mixed free and directed associative experiment for the study of nominations of concepts Е-ПРОСТIP (Е-SPACE) and КІБЕРПРОСТІР (CYBERSPACE) of the conceptual field "простір (space)" in the online mode. The purpose of the associative experiment is to confirm or refute the hypothesis that E-SPACE and CYBERSPACE are identical subconcepts of CF «простір». The article presents the reasons for choosing an associative experiment and the methodology of the experiment. The material of the research was 86 questionnaires of Ukrainian-, English- and Russian-speaking respondents who are carriers or mediators of the Ukrainian conceptual picture of the world and 955 reactions were collected. On the basis of free and directed answers, the respondents' reactions to the E-ПРОCTIP and КІБЕРПРОСТІР stimulus, the nominative field of two concepts was singled out, and 7 microfields of the Е-ПРОСТІР verbalization and 6 microfields of the KІБЕРПРОСТІР nomination were singled out. The top list of tokens of verbalizations of the concepts is presented in the article. The common conceptual constant based on the associative field of both concepts, and the status of subconcepts of the conceptual field «простір» was confirmed.

Keywords: information, reactions, tokens-representatives, conceptual field, picture of the world, logosphere, language personality, top-list.

\section{DOI: https://doi.org/10.23856/4408}

\section{Introduction}

In recent decades, new cells, sizes, and environments in the space have appeared that change the way we think about space. Outer space, the Internet, virtual reality are abstract dimensions limited only by human perception. Personal experience of spatial relations is changing and needs to be restored. Information, as a physical and philosophical concept, a measure of the heterogeneity of the distribution of matter and energy in space and time, a measure of change that accompanies all processes occurring in the world (Glushkov, 1986) is a key agent of change in spatial experience. "Forget Space-Time: Information May Create the Cosmos": information is both a mean and a fixer of change in the world (Kuhn, 2015), just as language is. Physicists use numbers to describe space, and programmers use the same numbers as language to create and actualize it. 
The philosophical category of space for division and cognition of the world has undergone conceptual changes. Human used to structure space through information about his location, and now, as a continuation of himself, human has placed information about himself in a container - electronic space. Various nominations have become established in the language of speakers: electronic space (S. Sassen, K. Robins, M. Hepworth, etc.), cyberspace (W. Gibson, S.B. Barnes, M. Benedikt, etc.). The question arises: what is the difference between these two cells of space? Whether they are two concepts that have something in common with SPACE or not and what is the difference between them we want to define with the help of verbalizations of these concepts. Thus, the relevance of the study is in the need to establish conceptual boundaries, common ideas about new concepts, to establish their cognitive relationship to the category of space represented in language in the form of the concept "SPACE" and the conceptual field around it.

\section{Literature review}

Space exists where we know about it. The rest has not been proven. Thus, as K. Popper said, the fact that we have not seen a black swan does not mean that it does not exist, and by claiming that it does not exist, we contradict the existence of those swans that are recorded (Popper, 1959: 111,378,404). However, we will not be able to describe the black swan until we see it (empirical experience). Therefore, that hypothetical space beyond the planets we have reached and described is a hypothetical space. Therefore, the emergence of information space is caused by the desire to capture the space under human control.

Our hypothesis is that in the national Ukrainian logosphere of being, E-space is identical to cyberspace. To prove that, we firstly studied previous linguistics researches. As Frege said in his theory of language sign: "The regular connexion between a sign, its sense, and its reference is of such a kind that to the sign there corresponds a definite sense and to that in turn a definite reference, while to a given reference (an object) there does not belong only a single sign" (Frege, 1952: 24). We aim to find in the concepts Е-ПРОСТІР and КІБЕРПРОСТІР the invariable essence, the common meaning of two different signs, a conceptual constant that we define as 1) as a common unshakable semantic base of the concept which remains in the variation of the names of the concept within one linguistic picture of the world; 2) the point of cultures contact, common denotation, fixed representation, the meaning of the concept common to the same concept within different linguistic pictures of the world, which is expressed in language by a token or tokens and reproduced in other comparable linguistic pictures of the world.

All the variety of verbalizations of the concepts of Е-ПРОСТІР and КІБЕРПРОСТІР will help us to establish such a constant. Reactions to e-space and cyberspace are embodied in the form of language, ie verbalized reactions, emotions, have the opportunity to establish the experience of the speaker in relation to the studied phenomena. Such reactions "are caused by the previous experience and due to them, one idea that appears in the mind causes new ideas on the basis of similarity, contiguity or opposite" (Klimkova, 1991: 45) and are called associations. Telia considers three types of associations: national-cultural, which are inherent in the bearers of a certain ethnolinguistic culture; general cultural, which are universal for speakers of different languages; and individual-authorial, or subjective (Telia, 1986: 91). As part of the study of CF "space" by exploring all the possible types of the associations around the sub-concept of Е-ПРОСТІР, КІБЕРПРОСТІР, we will be able to establish a separate associative field inside the CF "space". An associative field (associative group) is a set of words associated in a person's mind with a word (Bilodid, 1980: 298). 
The study of the connection between language and digitalization (Makhachashvili, Semenist 2020: 196), about the role of associations in concept shaping (Vorobyova, 2013; Prikhodko, 2013) and in concept dynamics (Dzyubenko, 2013; Surmach, 2012) were conducted before. The study of the connection between the concept, digitalization and associative linguistic experiment study is poorly presented in linguistic research (Klyuyev, 2020; Agagyulova, 2012) and need futher deep development.

Based on the ethnolinguistic relativity "Humboldt - Sepir - Wharf", we consider the two-way process of language influence on man and man on language. Knowing the language, a person owns its conceptual picture of the world (CPoW). It extends the angle of view to the objects of reality. "The reverse effect of language is all the more definite because through it everything created by peoples in the past affects the individual" (Humboldt,1985). Hence the idea that if a language has a cultural specificity, then mastering the language includes mastering CPoW of a particular culture. Thus, the mediators of such CPoW are not only the native speakers (in the traditional sense, those for whom the language is native), but also those representatives of other cultures who speak and undertand another language. A person in the language aspect is considered as a language personality and has a three-level structure of language acquisition: verbal level, the level of the picture of the world and the level of communicative needs (Karaulov, 2010). If we take native speakers, they are fluent in the language and have all three levels, while those who know the language, although not traditional speakers, but are able to operate with words and concepts that are hidden behind them and thus act as mediators of the linguistic picture of the world (LPoW) and CPoW hidden behind it. "Verbalized knowledge is represented by concepts - operational units of the conceptual picture of the world. Those concepts that are connected by verbal codes represent operative units of the linguistic picture of the world and form "internal vocabulary" as objectified knowledge in language" (Drach, Mykolenko, Tyshkovet, 2019). The inner lexicon is a reservoir for concepts (Bila, 2020: 7). Thus, associations, as an internal lexicon of personality, are an example of that objectified knowledge in the language of CPoW.

Thus, the CPoW mediator - we define the person who obtains the language as an instrument of the LPoW, which in its activities is the subject implementation of the CPoW. Thus, we took into account the results of the survey not only of native Ukrainian speakers. Within the CF there are units of intercultural logosphere "space" - a set of all language units from all the LPoW in the world, all the world models (Makhachashvili, Semenist 2020:196), which is conditionally verbalization of abstract and empirical elements of the category of space.

Thus, the purpose of the study is to establish the common semantics of the subconcepts Е-ПРОСТІР and КІБЕРПРОСТІР with which they entered the conceptual field «Простір» due to the expansion of information space.

\section{Methodology}

To reach the aim, we will use the method of psycholinguistic associative experiment that is explained by the specific of the object of study. "Human mind is a close system and one cannot observe its processes directly. Hence linguistics has to neglect the main methods of studying such as observation and introspection and to apply experimental techniques" (Vasianovych, 2020: 110).

The technique of associative-semantic experiment is often used to study the associative field of concepts. It makes it possible to identify a set of paradigmatically and syntagmatically 
related verbal representatives of concepts in the text, as well as a system of associations generated by them (Surmach, 2012).

When studying the conceptual field of «простір» and identifying the real modern picture of its structure we employ a mix of two of three types of associative experiment suggested by Glukhov. It is a free associative experiment (Glukhov, 2005) aimed at establishing new tokens in the conceptual field. A purposeful experiment (Glukhov, 2005), on the other hand, can establish tokens that are traditionally associated with the concept but are already obsolete or obsolete, and on the contrary confirm the relevance of other already known ones. Thus, a mixed associative experiment should allow for a complete associative description of the word stimulus, which may be the concept itself. The stimuli for the reactions were given in the written form, presented to the respondents by the Google Form questionnaire online.

The material of the research is the answers of the respondents left in the questionnaire submitted in the electronic online form in Google Forms. 105 questionnaires were collected: 56 questionnaires in Ukrainian, 30 questionnaires were collected in Russian, 13 questionnaires in English and 6 in French.

We believe that in the context of internationalization, globalization and widespread use of foreign language vocabulary, associations of respondents may arise in different languages. Also, we do not rule out the possibility of bilingual respondent that is typical for Ukraine. Thus, we identified three groups of kepers of CPoW as respondents of the questionaire based on the obtained data: 1) Respondents whose answers were in Ukrainian (speakers of CPoW); 2) Respondents who chose Ukrainian as their native language, but whose answers were in a foreign language (speakers of $\mathrm{CPoW}$ ); 3 ) Respondents who indicated Ukrainian as a language they spoke but answered in a foreign language ( $\mathrm{CPoW}$ mediators). As a result, 86 questionaires out of 105 were studied.

Socio-cultural background of reactions was identideied by the first 4 uestions in the qiestionaire. Age of participants: 86 respondents voluntarily participated in the survey aged 15 to 51 years. Gender of participants: $82.56 \%$ of respondents were women, and $17.44 \%$ were men, or 15 men and 71 women. Mother tongue: for 21 respondents Russian is their mother tongue and for 66 respondents out of 86 Ukrainian is their mother tongue (one of whom identified himself as bilingual).

In this article we represent and analyze the reactions given to the questions № 6,7,11,14 of the questionnaire that aimed to build definition, synonymous sequence around cocnepts Е-ПРОСТІР and КІБЕРПРОСТІР.

\section{Results to stimulus «E-ПРОCTIP»}

Among the respondents who answered in Ukrainian, $7.1 \%$ chose the interpretation of the abromorpheme e-as "emotional", and $92.9 \%$ of respondents chose the definition of e-space as "electronic space".

As a result of answering question № 6, a list of 348 reactions were gathered. 247 free associations in Ukrainian was compiled, 116 reactions tokens verbalizing it are repetitive, and the other 131 reactions are represented by a token only once. Reactions are presented in descending order, except for unique reactions: 
Table 1

Free reactions to the stimulus E-ПPOCTIP in Ukrainian

\begin{tabular}{|c|l|c|c|l|c|}
\hline & \multicolumn{1}{|c|}{ Reaction } & Frequency & & \multicolumn{1}{c|}{ Reaction } & Frequency \\
\hline 1. & Інтернет & 14 & 17. & Де & 3 \\
\hline 2. & Простір & 11 & 18. & В & 3 \\
\hline 3. & Інформація & 7 & 19. & Чьогось & 2 \\
\hline 4. & Мережі & 6 & 20. & Технології & 2 \\
\hline 5. & Електронний & 5 & 21. & Онлайн & 2 \\
\hline 6. & Спілкування & 4 & 22. & Нова & 2 \\
\hline 7. & Соціальні & 4 & 23. & Інформаційний & 2 \\
\hline 8. & Навчання & 4 & 24. & Який & 2 \\
\hline 9. & Можливості & 4 & 25. & Доступ & 2 \\
\hline 10. & Комунікація & 4 & 26. & Свобода & 2 \\
\hline 11. & Електронна & 4 & 27. & Для & 2 \\
\hline 12. & Середовище & 3 & 28. & Різних & 2 \\
\hline 13. & Мережа & 3 & 29. & База & 2 \\
\hline 14. & Комп’ютер & 3 & 30. & Даних & 2 \\
\hline 15. & Інформації & 3 & 31. & Зручність & 2 \\
\hline 16. & Доступність & 3 & 32. & Нова & \\
\hline
\end{tabular}

Among the 30 questionnaires of respondents mediators of Ukranian CPoW, who answered other proposed languages, 73\% deciphered the abromorpheme e- as "electronic": 10 respondents answered in another language (Russian and English) but indicated Ukrainian as their mother tongue, 12 respondents indicated Ukrainian as their language and deciphered e-as "electronic". Respondents who gave answers in French did not choose the electronic option as a reaction to the abromoframe e-, so their answers are not included in the associative studies of Е-ПРОСТIP. In total in another 101 free reactions collected, 72 of them are unique:

Table 2

Free reactions to the stimulus E-ПPOCTIP in Russian and English of Ukrainian CPoW meadiators

\begin{tabular}{|c|l|c|}
\hline & \multicolumn{1}{|c|}{ Reaction } & Frequency \\
\hline 1. & Интернет & 6 \\
\hline 2. & Онлайн & 4 \\
\hline 3. & Информация & 3 \\
\hline 4. & Сеть & 3 \\
\hline 5. & Электронный & 3 \\
\hline 6. & In & 2 \\
\hline 7. & Internet & 2 \\
\hline 8. & Доступ & 2 \\
\hline 9. & Пространство & 2 \\
\hline 10. & Технологии & 2 \\
\hline
\end{tabular}

Taking into account 348 reactions recieved to the question № 6 in all the languages, the ten most common tokens of free reactions to the E-ПPOCTIP stimulus were singled out from the mediators of the Ukrainian CPoW: 
Top-11 tokens of free verbalization of the concept E-IIPOCTIP by Ukrainian CPoW keepers

\begin{tabular}{|c|l|c|c|c|}
\hline \multicolumn{1}{|c|}{ Token } & Frequency & $\begin{array}{c}\text { Among them } \\
\text { NOT in Ukrainian }\end{array}$ & $\%$ \\
\hline 1. & Інтернет & 22 & 8 & 6,32 \\
\hline 2. & Інформація & 14 & 4 & 4,02 \\
\hline 3. & Простір & 13 & 2 & 3,73 \\
\hline 4. & Електронне & 11 & 3 & 3,16 \\
\hline 5. & Мережа & 10 & 4 & 2,87 \\
\hline 6. & Соціальне & 8 & 1 & 2,29 \\
\hline 7. & Навчання & 7 & 4 & 2,01 \\
\hline 8. & Онлайн & 6 & 1 & 1,72 \\
\hline 9. & Спілкування & 5 & - & 1,43 \\
\hline 10. & Комунікація & 4 & 2 & 1,14 \\
\hline 11. & Доступ & 4 & & 14 \\
\hline
\end{tabular}

The tokens in the table 3 presents the new tokens of conceptual field "space" as Iнтернет, онлайн.

If in the previous question № 6 we collected definitions, now we clarify the core area by finding synonyms in the answers of respondents, similarly to the tokens-representatives which were embodied in lexicographic sources.

The task of the question № 7 was to establish purposeful associations in the form of token-reactions in the form of nouns and noun-constructions. A total of directed reactions were collected. 255 reactions: 122 repeated and 133 unique.

184 reactions were collected in Ukrainian, 84 of them are unique. Among the 184 reactions most commonly used for category 1 respondents were:

Table 4

Dircted noun-reactions to the stimulus E-ПРОСТIP in Ukrainian

\begin{tabular}{|c|l|c|c|l|c|}
\hline & \multicolumn{1}{|c|}{ Reaction } & Frequency & & \multicolumn{1}{c|}{ Reaction } & Frequency \\
\hline 1. & Інтернет & 21 & 14. & Доступ & 2 \\
\hline 2. & Мережа & 8 & 15. & Місце & 2 \\
\hline 3. & Навчання & 8 & 16. & Пошук & 2 \\
\hline 4. & Інформація & 6 & 17. & Телефон & 2 \\
\hline 5. & Можливості & 5 & 18. & Розвиток & 2 \\
\hline 6. & Комп'ютер & 5 & 19. & Слово & 2 \\
\hline 7. & Комунікація & 5 & 20. & Доступінсть & 2 \\
\hline 8. & Середовище & 5 & 21. & Платформа & 2 \\
\hline 9. & Спілкування & 3 & 22. & Зв'язок & 2 \\
\hline 10. & Швидкість & 3 & 23. & Сайт & 2 \\
\hline 11. & Знання & 3 & 24. & Простота & 2 \\
\hline 12. & Допомога & 2 & 25. & Екран & 2 \\
\hline 13. & Дослідження & 2 & 26. & Телефон & 2 \\
\hline
\end{tabular}


71 reactions were gathered in another language, 51 are unique: Respondents who gave answers in French did not choose the electronic option as a reaction to the abromoframe e-, so their answers are not included in the associative studies E-ПPOCTIP.

Directed noun-reactions to the stimulus E-ПPOCTIP

Table 5 in Russian and English of Ukrainian CPoW meadiators

\begin{tabular}{|c|l|c|}
\hline & \multicolumn{1}{|c|}{ Reaction } & Frequency \\
\hline 1. & Интернет & 5 \\
\hline 2. & Сеть & 3 \\
\hline 3. & Скорость & 3 \\
\hline 4. & Технологии & 3 \\
\hline 5. & Знания & 2 \\
\hline 6. & Мир & 2 \\
\hline 7. & сайт & 2 \\
\hline
\end{tabular}

Considering all the received 255 reactions to the question № 7 in Ukrainian, Russian and English, the nine most common tokens of directed reactions to the E-SPACE stimulus were singled out from the mediators of the Ukrainian CPoW:

Table 6

Top-9 directed tokens ofdirected verbalization of the concept E-ПPOCTIP by Ukrainian CPoW keepers

\begin{tabular}{|c|l|c|c|c|}
\hline \multicolumn{1}{|c|}{ Token } & Frequency & $\begin{array}{c}\text { Among them } \\
\text { NOT in Ukrainian }\end{array}$ & Quality \% \\
\hline 1. & Інтернет & 26 & 6 & 10,19 \\
\hline 2. & Мережа & 12 & 4 & 4,70 \\
\hline 3. & Інформація & 9 & 3 & 3,52 \\
\hline 4. & Навчання & 9 & 1 & 3,52 \\
\hline 5. & Комунікація & 7 & 1 & 2,74 \\
\hline 6. & Компютер & 7 & 1 & 2,74 \\
\hline 7. & Швидкість & 6 & 3 & 2,35 \\
\hline 8. & Середовище & 6 & 1 & 2,35 \\
\hline 9. & Можливості & 5 & - & 1,96 \\
\hline
\end{tabular}

A total of 603 reactions were collected, 282 of which were collectively recognized, which is $46.7 \%$ of all reactions and are presented in the form of 52 repeating tokens with different frequencies. The second part consists of 321 unique reactions, which is $53.2 \%$ of all reactions and corresponds to 263 unique tokens in three languages: Ukrainian, Russian and English. microfields:

According to the definitions presented by other respondents, there are 7 semantic

E-ПPOCTIP :: INFORMATION : де наявна потрібна нам інформачія, безліч інформації, якесь вмістилище чи протяжність чогось, зміни, знання, технологї, Бібліотеки, статті, тести онлайн; нова система пошуку чогось, типу вікіпедія; мова, контекст, безліч формації, база корисних даних, Электронный курс, Дистанционка, Учеба, онлайн конференциии еtс; 
E-ПРОСТIP :: POSSIBILITIES : можливості, простір для онлайн комунікацї; електронна мережа, де можна виконувати ряд дій; саморозвиток, маніпуляція, соціалізація, уподобання, проведення навчально-наукових досліджень, илях до саморозвитку, обмін інформачією, накопичення інформаџіï, середовище для розвитку $і$ навчання, місие дослідження носіїв різних мов, нові можливості, один з шляхів до саморозвитку, навчання, зв'язок, мобільність, ивидкість, виклики, доступ, A place in the internet for sharing educational nfo, Пространство для общения, Свободное место для размышлений, еtc;

E-ПPOCTIP :: ANALOG OVERALL ENVIRONMENT : Космос, Вселенная, всемирная паутина, простір, евклідів простір, изифровий світ, електронний простір, параллельный мир, виртуальное общество, неземное смешанная реальность, digital environment in which we regularly function, Iнтернет, Интернет, сеть интернет, мережа, онлайн, платформа, форум сочмережа, соціальна мережа, група, фальш, пошуковик, блог, сайт, електронна пошта, код, віртуальна реальність, пошукова система, спільнота, Фейсбук,гул, cloud, social networks;

E-ПРОСТIP :: DEVICES: пристрій, Екран, засіб, Комп'ютер, електрон, технологія технології, телефон, ікт, ноутбук, смартфон сотритег;

E-ПPOCTIP :: SOCIAL INTERACTION : спілкування chats, веб-сайты, браузер, сочіальні мережі, величезний спільний чат, оточення; сочіальна мережа, сочіальне медіа, аккаунт в Інтернеті, блог, електронна платформа, соимережі,співпрачя;

E-ПPОСТIP :: GOOD: незалежність, простір де комфортно, иікаво,безпечно, легкість, простота, успіх, легкодоступність;

E-ПРОСТIP :: LIMIT: територія область, иир, розмах місие розташування простір середовище сфера, земля, повітря, дім, свобода, українське, молодість дорослі.

Thus, based on free and directed associations of respondents, we get the following nominative field of the concept "E-SPACE":

Associative field of concept E-ПPOCTIP

Table 7

\begin{tabular}{|c|l|c|c|}
\hline \multicolumn{1}{|c|}{ Tokens } & Frequency & Quality \% \\
\hline 10. & Інтернет & 48 & 7,96 \\
\hline 11. & Інформація & 23 & 3,814 \\
\hline 12. & Мережа & 22 & 3,64 \\
\hline 13. & Навчання & 16 & 2,65 \\
\hline 14. & Простір & 14 & 2,32 \\
\hline 15. & Комунікація & 11 & 1,82 \\
\hline 16. & Середовище & 11 & 1,82 \\
\hline 17. & Комп'ютер & 11 & 1,82 \\
\hline 18. & Можливості & 10 & 1,65 \\
\hline 19. & Соціальне & 10 & 1,65 \\
\hline 20. & Спілкування & 9 & 1,49 \\
\hline 21. & Онлайн & 8 & 1,32 \\
\hline 22. & Швидкість & 7 & 1,16 \\
\hline 23. & Доступ & 6 & 0,99 \\
\hline
\end{tabular}

The tokens are given in table 3 tokens (14) Інтернет, інформація, мережа, навчання, простір, комунікація, середовище, комп'ютер, можливості, соціальне, спілкування, 
оналйн, швидкість, доступ we define similar to the definitions collected in lexicographic sources and relate them to the zone of CF "space".

\section{Results to stimulus KIБEPПРОСТIP}

A synonym for e-space was chosen as cyberspace by 35 respondent answering in Ukrainian out of 52, by 5 respondents answering in Russian, 3 in English while having Ukrainian as native, and by 8 repondents out of 12 respondents answered in Russian but mediators of Ukranian CPoW.

In 201 respondents' tokens-reactions, the cyberspace is the synonym to the electronic space. They describe it in questions № 11 with 132 free reactions via the following 36 repeated tokens and 96 unique:

Table 8

Free reactions to the stimulus КІБЕРПРОСТIP in Ukrainian

\begin{tabular}{|c|l|c|c|l|c|}
\hline & \multicolumn{1}{|c|}{ Reaction } & Frequency & & \multicolumn{1}{c|}{ Reaction } & Frequency \\
\hline 1. & Інтернет & 8 & 11. & Спілкування & 2 \\
\hline 2. & Інформація & 6 & 12. & Інформаційне & 2 \\
\hline 3. & Мережа & 5 & 13. & Система & 2 \\
\hline 4. & Технології & 5 & 14. & Ігри & 2 \\
\hline 5. & Світ & 4 & 15. & Віртуальний & 2 \\
\hline 6. & Середовище & 4 & 16. & Електронний & 2 \\
\hline 7. & Безпека & 3 & 17. & Сучасність & 2 \\
\hline 8. & Простір & 3 & 18. & Дані & 2 \\
\hline 9. & Штучний & 2 & 19. & Де & 2 \\
\hline 10. & Небезпека & 2 & & & \\
\hline
\end{tabular}

Ambiguous 69 reactions with a low frequency presentation were given by respondents who answered in the questionnaire in by English and Russian tokens. 15 reactions verbilzed by tokens were repeated and 54 reactions are unique:

Table 9

\section{Free reactions to the stimulus КІБЕРПРОСТІР in Russian and English of Ukrainian CPoW meadiators}

\begin{tabular}{|c|l|c|}
\hline & \multicolumn{1}{|c|}{ Reaction } & Frequency \\
\hline 1. & Интернет & 4 \\
\hline 2. & Технологии & 3 \\
\hline 3. & Информация & 2 \\
\hline 4. & Виртуальная & 2 \\
\hline 5. & Реальность & 2 \\
\hline 6. & Пространство & 2 \\
\hline
\end{tabular}

From the given reaction in Ukrainian by the Ukrainian native speakers, in Russian and English by the Ukrainians and in Russian and English by the mediators of CPoW of Ukrainian we may point out 8 high-ranked tokens that used to verbalize concept КІБЕРПРОСТІР by the representors of all the studied 3 groups of Ukrainian CPoW keepers: 
Table 10

Top-8 tokens of free verbalization of the concept КІБЕРПРОСТIP by Ukrainian CPoW keepers

\begin{tabular}{|c|l|c|c|c|}
\hline \multicolumn{1}{|c|}{ Reaction } & Frequency & $\begin{array}{c}\text { Among them } \\
\text { NOT in Ukrainian }\end{array}$ & Quality \% \\
\hline 1. & Інтернет & 12 & 4 & 5.97 \\
\hline 2. & Інформація & 8 & 2 & 3,98 \\
\hline 3. & Технології & 8 & 3 & 3,98 \\
\hline 4. & Мережа & 6 & 1 & 2.98 \\
\hline 5. & Середовище & 5 & 1 & 2.48 \\
\hline 6. & Простір & 5 & 2 & 2.48 \\
\hline 7. & Безпека & 4 & 1 & 1.99 \\
\hline
\end{tabular}

The task of the question № 14 was to establish directed associations in the form of token-reactions to КІБЕРПРОСТІР in the form of nouns and noun-constructions. A total of 151 reactions were collected. 102 reactions presented by respondents of the 1st category were, 41 reactions were unique:

Table 11

Dircted noun-reactions to the stimulus КІБЕРПРОСТIP in Ukrainian

\begin{tabular}{|c|l|c|c|l|c|}
\hline & \multicolumn{1}{|c|}{ Reaction } & Frequency & & \multicolumn{1}{|c|}{ Reaction } & Frequency \\
\hline 1. & Інтернет & 6 & 9. & Дані & 4 \\
\hline 2. & Інформація & 5 & 10. & Майбутнє & 4 \\
\hline 3. & Мережа & 5 & 11. & Інтелект & 3 \\
\hline 4. & Комунікація & 5 & 12. & Пошук & 3 \\
\hline 5. & Технології & 5 & 13. & Технологія & 2 \\
\hline 6. & Комп“ютер & 5 & 14. & Знання & 2 \\
\hline 7. & Система & 4 & 15. & Навчання & 2 \\
\hline 8. & Середовище & 4 & 16. & Простір & 2 \\
\hline
\end{tabular}

Respondents- mediators of Ukrainian CPoW gave 48 directed reactions to the stimulus КІБЕРПРОСТІР: 14 reactions are repeated by the tokens presented in the table, the other 36 reactions are unique.

\section{Directed noun-reactions to the stimulus KIБЕРПРОСТIP in Russian and English of Ukrainian CPoW meadiators}

\begin{tabular}{|c|l|c|}
\hline & \multicolumn{1}{|c|}{ Reaction } & Frequency \\
\hline 1. & Интернет & 5 \\
\hline 2. & Защита & 2 \\
\hline 3. & Информация & 2 \\
\hline 4. & Среда & 2 \\
\hline 5. & Сеть & 2 \\
\hline
\end{tabular}

It is necessary to mention that only 1 respondent intentionally did not provide verbalized reaction to the stimulus cyberspace. Among the rest of 150 directed 
reactions in Ukrainian, Russian and English the top-list of tokens verbalizing the concept КІБЕРПРОСТІР includes:

Table 13

Top 10 tokens ofdirected verbalization of the concept КІБЕРПРОСТIP by Ukrainian CPoW keepers

\begin{tabular}{|c|l|c|c|c|}
\hline & Reaction & Frequency & $\begin{array}{c}\text { Among them } \\
\text { NOT in Ukrainian }\end{array}$ & Quality \% \\
\hline 1. & Інтернет & 11 & 5 & 7,28 \\
\hline 2. & Інформація & 8 & 3 & 5,29 \\
\hline 3. & Технологї & 8 & 1 & 5,29 \\
\hline 4. & Мережа & 8 & 3 & 5,29 \\
\hline 5. & Комп'ютер & 6 & 1 & 3,97 \\
\hline 6. & Середовище & 5 & 2 & 3,97 \\
\hline 7. & Комунікація & 5 & - & 3,31 \\
\hline 8. & Дані & 5 & 1 & 3,31 \\
\hline 9. & Майбутнє & 4 & 1 & 3,31 \\
\hline 10. & Інтелект & & 1 & 2.64 \\
\hline
\end{tabular}

Based on the answers from the questionnaires of all 3 groups of respondents, on the questions № 11 and № 14 including repeated and unique tokens we distinguish the following microfields of the concept of КІБЕРПРОСТІР on the basis of their thematic compatibility: "digital"; caused by the digital nature of the second microfield "artificial world"; artificial environment "Internet" and its components; modernity ; risk and possibility.

КІБЕРПРОСТIP :: DIGITAL: кодування, програмування, автоматизований програмований спосіб отримання інформації, кодування, іт-технології, подвійний иифр, цчифровий простір, цчифровая среда, цчифра кібернетика, код;

KIБEPПРОСTIP :: ARTIFICIAL WORLD: ілюзія, нереальний світ, іниий світ, світ бажань, електронний світ, штучність, штучний інтелект, знаючі люди, прагматичність, ігри, певне «місце» в комп 'ютерному середовищі, де знаходяться всі дані та програми, місце - де машини головні, роботизований простір, комп ютерна система, техника, интеллект, искусственный, компьютерные системы, мир, gaming, environment in which human interaction is mediated by ai, поглощающий нереальный мир, абстракція, операционные системы, інженер робот життя. Actually, the creator of the term W. Gibson himself spoke about artificiality, "hallucinogenicity" of cyberspace in life without science fiction Neuromancer (Gibson, 1984:47) explaining that it is simply an abstract collection of graphical representations of human life in a computer;

КІБЕРПРОСТIP :: INTERNET: Інтернет, середовище пов'язане з новітніми технологіями та інтернетом, увесь інтернет, світова павутина, онлайн, глобальна мережа, платформи, блоги, сочіальні мережі, е-пошта, віртуальний простір мережі виртуальная реальность, интернет, он-лайн, google drive, moodle and any other platform for co-working, platform,комп'ютер, виртуальная реальность, сеть интернет, технологи, скайп, сервер, гугл;

КIБЕРПРОСТIP :: MODERNITY: сучасність, інновачіï futиге, мультифункиіональність, інтерактивність, нова історія, прогрес, новизна; 
КІБЕРПРОСТIP :: RISK: небезпека, безпека спілкування, невизначеність, інформаиійна безпека, защитта, кибербезопасность, осторожность, хакерство, анонимность атака;

КІБЕРПРОСТIP :: POSSIBILITIES: інформачүійне середовище, інформачійний простір, обмін, доступ, підключення, отримання, спосіб, накопичення, спілкування, навчання, можливості, вдосконалення, робота, медіа, є основою для можливості існування космополітичного суспільства, глобалізачія, підключення, розуміння, комунікації, дані, телекомунікації, информация, учеба информационная середа, co-working, sharing, coтmипісаtion, широкие возможности, свобода, онлайнт, послуги.

Based on 352 free and directed associations to the stimulus of КІБЕРПРОСТIP, we fix the following nominative field of the concept «КІБЕРСПРОСТІР»:

\section{Associative field of concept КІБЕРПРОСТIP}

Table 14

\begin{tabular}{|c|l|c|c|}
\hline & \multicolumn{1}{|c|}{ Tokens } & Frequency & Quality \% \\
\hline 1. & Інтернет & 24 & 6,81 \\
\hline 2. & Інформація & 21 & 5,96 \\
\hline 3. & Технології & 17 & 4.82 \\
\hline 4. & Мережа & 14 & 3.97 \\
\hline 5. & Середовище & 12 & 3,40 \\
\hline 6. & Система & 9 & 2,55 \\
\hline 7. & Комунікація & 8 & 2.27 \\
\hline 8. & Комп'ютер & 7 & 1,92 \\
\hline 9. & Простір & 7 & 1,92 \\
\hline 10. & Дані & 6 & 1,70 \\
\hline 11. & Інтелект & 6 & 1,70 \\
\hline 12. & Майбутнє & 5 & 1,42 \\
\hline 13. & Безпека & 4 & 1,13 \\
\hline
\end{tabular}

\section{Conclusions}

As a result of the mixed free and directed asscoiative experiment, 955 reactions were collected. Accorfing to the associations given by the three groups of CPoW keepers specific and common features of concepts Е-ПРОСТІР and КІБЕРПРОСТІР are the following:

Spesific quantitative features of the nomination of the concept of E-ПРОСТIP presented by the tokens: навчання, рростір, можливості, соціальне, онлайн, доступ. From here we can talk about the educational and cognitive, socially useful nature of e-space. Microfileds distinguished in the conceptual field of subconcept E-ПPOCTIP are INFORMATION, POSSIBILITIES, ANALOG OVERALL ENVIRONMENT, DEVICES, SOCIAL INTERACTION, GOOD, LIMIT.

Cyberspace was distinguished by such tokens-reactions as система, дані, інтелект, майбутнє, итучне, безпека. Based on the semantical relativeness of the reactions collected we distinguished 5 microfields inside the concept KІБЕРПРСОТIP: DIGITAL, ATIFICIAL WORLD, INTERNET MODERNITY, RISK, POSSIBILITIES. Thus, the key feature of the concept of КІБЕРПРОСТІР is based on its digital nature and related artificial life, robots, professionals who know how to operate such numbers, codes and around the state of information security. 
As a result of elaboration of token-reactions on stimuli Е-ПРОСТІР and КІБЕРПРОСТІР, we may conclude that they are used with synonymous meaning for $59 \%$ of respondents. It is proved not only by the individual definitions and noun-associations to the concepts in open and directed questions, but also the frequency of representations of such common conceptual constants of both concepts. If we compare the data received about the associative fields of Е-ПРОСТІР and КІБЕРПРОСТIP concepts we may state that Е-ПРОСТIP and КІБЕРПРОСТІР is the Інтернет 7,53\%, інформаиія 4.60\%, мережа 3,76 \% середовище $2,40 \%$, простір $2,19 \%$, комунікаиія $1,98 \%$, комп'ютер $1,88 \%$.

The comon feature of is POSSIBILITIES like communication, and the form of another ANALOG or ARFTIFICAL WORLD.

Thus, the obtained tokens-representatives of the concepts Е-ПРОСТIP and КІБЕРПРОСТІР are included in CF “space". The tokens Iнтернет, комп'ютер, швидкість, електронний, онлайн, система, дані, база, сайт, майбутнє, інтерактивний, віртуальний, иифровий, were not previously included to CF "space" and as a result of activity of information with space now enter into the draft of the concept «ПРОСТIP», through CF «простір».

Expansion of CF "space": as a result of obtaining data from a mixed associative experiment, the concepts Е-ПРОСТІР and КІБЕРПРОСТІР are established as subconcepts of two conceptual fields SPACE and INFORMATION which have the following conceptual constant: Е-ПРОСТIP and КІБЕРПРОСТIP: is an ELECTRONIC COMPUTER ENVIRONMENT to search INFORMATION by HIGH-SPEED COMMUNICATION via the INTERNET. Thus, their ability to expand CF "space" is confirmed, and the relation of concept Е-ПРОСТІР and КІБЕРПРОСТІР to it as subcocnepts was proved by their definition as the environment.

The study was conducted within the project of the Department of Romance Languages and Typology (Borys Grinchenko Kyiv University, Kyiv, Ukraine) "European Languages and Literatures Development in the Framework of Intercultural Communication", registration code $0116 \mathrm{U} 00660$.

\section{References}

Agagyulova S.I. Obrazno-pertseptivnyye kharakteristiki kontsepta "Internet" v professional'nom yazykovom soznanii [Figurative and perceptual characteristics of the concept "Internet" in the professional linguistic consciousness]. Internet-kommunikatsiya kak novaya rechevaya formatsiya: koll. monografiya. Ed. Kolokol'tseva, T.N., Lutovinova, O.V. Moscow: FLINTA: Nauka, 109 - 124.

Bila, Y. (2020). COGNITIVE ONOMASTICS: SEMANTIC GESTALTS OF THE ASSOCIATIVE ONYMIC FIELD OF AROMATONYMS. Scientific Journal of Polonia University, 38(1-2), 6-15. https://doi.org/10.23856/3841

Bilodid, I. (1980). Slovnyk ukrayins'koyi movy: $v 11$ tt. [Dictionary of the Ukrainian language: in 11 vols.]. Kyiv: Naukova dumka [in Ukrainian]

Drach, I.D.,Mykolenko,A.Z.,Tyshkovets, M.P. (2019) Movna kartyna svitu u protsesi vyvchennya inozemnoyi movy $v$ medychnykh universytetakh [Linguistic picture of the world in the process of learning a foreign language in medical universities]. Medychna osvita, 79-83, [in Ukrainian] Dzyubenko, O.M. (2013). Dynamika rozvytku kontseptu uchytel' (na materiali epitetiv literaturno-khudozhn'oho dyskursu latyns'koyi, anhliys'koyi ta ukrayins'koyi mov). [Dynamics of development of the concept of teacher (on the material of epithets of literary and artistic discourse of Latin, English and Ukrainian languages] Naukovi zapysky [Natsional'noho 
universytetu “Ostroz'ka akademiya”, 38, 177-179. Retrieved from: http://nbuv.gov.ua/UJRN/ Nznuoaf_2013_38_56 [in Ukrainian]

Frege, $\bar{G} .(19 \overline{52})$. On sense and reference. In: Translations from the Philosophical Writings of Gottlob Frege. P. Geagh, M. Black [eds.]. Oxford. Retrieved from: https://home.sandiego. edu/ baber/metaphysics/readings/Frege.SenseAndReference.pdf

Gibson,W. (1984). Neuromancer. New York: BasicBooks.

Glukhov, V.P. (2005). Osnovy psikholingvistiki: ucheb. posobiye dlya studentov pedvuzov [Fundamentals of Psycholinguistics: Textbook. manual for students of pedagogical universities]. Moscow: ACT: Astrel [in Russian].

Glushkov, V.M. (1986). Kibernetika. Voprosy teorii i praktiki [Cybernetics. Questions of theory and practice]. Moscow: Nauka [in Russian]

Humboldt, W. (1985). Yazyk i filosofiya kul'tury [Background. Language and philosophy of culture]. Moscow: Progress, 1985[Russian traslation].

Karaulov, Yu.N. (2010) Russkiy yazyk i yazykovaya lichnost' [Russian language and language personality]. Moscow: Izdatel'stvo LKI. Retrieved from : https://www.twirpx.com/file/2016187/ Klimkova, L.A. (1991). Assotsiativnoye znacheniye slov v khudozhestvennom tekste [Associative meaning of words in a literary text]. Philological sciences, No. 1, 45-54 [in Russian].

Klyuev, N.A. (2020) Assotsiativno-verbal'naya set' kontsepta sotsial'nyye media / social media: dis.kand.fiilol.nauk [Associative-verbal network of the concept of social media / social media: dissertation: Candidate of Philological Sciences]. Perm: Perm State National Research University).

Kuhn, R.L. (2015) Forget Space-Time: Information May Create the Cosmos 2015. Resource online: https://www.space.com/29477-did-information-create-the-cosmos.html Acessed on 29.04.2021

Makhachashvili, R.K, Semenist I.V. (2021) Fenomenolohichni pryntsypy pobudovy hlobal'noyi innovatsiynoyi lohosfery komp"yuternoho buttya (na materiali yevropeys'kykh ta skhidnykh mov) Phenomenological principles of construction of the global innovative logosphere of computer existence (on the material of European and Eastern languages). Vcheni zapysky TNU imeni V. I. Vernads'koho, 32(71),195-202. ISSN 2710-4664

Popper, K. (1959) The Logic of Scientific Discovery. New York: Basic Books, P. 479.

Prikhodko, A.M. (2013). Kontsepty i kontseptosistemy [Concepts and concept systems]. Monograph. Dnepro-petrovsk: Belaya E.A. P. 307[in Russian].

Surmach, O.YA. (2012) Asotsiatyvnyy eksperyment ta verbal'ni asotsiatsiyi u psykholinhvistychnykh doslidzhennyakh [Associative experiment and verbal associations in psycholinguistic research]. Naukovi zapysky [Natsional'noho universytetu “Ostroz'ka akademiya”]. Ser. : Filolohichna, 29, 22-24. Retrieved from: http://nbuv.gov.ua/UJRN/Nznuoaf_2012_29_10 Telia, V.N. (1986) Konnotativnyy aspekt semantiki nominativnykh yedinits [Connotative aspect of the semantics of nominative units]. Moscow: Nauka. Pp. 143[in Russian].

Vasianovych, Y. (2020). PEACE AND WAR ASSOCIATIONS OF UKRAINIAN HUMANITIES STUDENTS. Scientific Journal of Polonia University, 38(1-2), 110-116. https:// doi.org/10.23856/3855

Vorobyova, O.V. (2013). Konceptologiya v Ukraine: obzor problematiki. (conceptology in Ukraine review of issues) Linguoconceptology: perspective directions: monograph. Ed. by A.E. Levitskiy, S.I. Potapenko, I.V. Neydanova. Luhansk: HU “LNU imeni Tarasa Shevchenko”. [in Russian]. Retrieved from: http://www.ndu.edu.ua/storage/injaz/duscuplinu/Potapenko_ lingvokonzeptologija.pdf [in Russian] 